\title{
Carbon carry capacity and carbon sequestration potential in China based on an integrated analysis of mature forest biomass
}

\author{
LIU YingChun ${ }^{1,2}$, YU GuiRui ${ }^{1 *}$, WANG QiuFeng ${ }^{1}$, ZHANG YangJian $^{1}$ \& XU ZeHong ${ }^{2}$ \\ ${ }^{1}$ Key Laboratory of Ecosystem Network Observation and Modeling, Institute of Geographic Sciences and Natural Resources Research, \\ Chinese Academy of Sciences, Beijing 100101, China; \\ ${ }^{2}$ Academy of Forestry Inventory and Planning, State Forestry Administration of China, Beijing 100714, China
}

Received January 13, 2014; accepted August 15, 2014; published online November 24, 2014

\begin{abstract}
Forests play an important role in acting as a carbon sink of terrestrial ecosystem. Although global forests have huge carbon carrying capacity $(C C C)$ and carbon sequestration potential $(C S P)$, there were few quantification reports on Chinese forests. We collected and compiled a forest biomass dataset of China, a total of 5841 sites, based on forest inventory and literature search results. From the dataset we extracted 338 sites with forests aged over 80 years, a threshold for defining mature forest, to establish the mature forest biomass dataset. After analyzing the spatial pattern of the carbon density of Chinese mature forests and its controlling factors, we used carbon density of mature forests as the reference level, and conservatively estimated the $C C C$ of the forests in China by interpolation methods of Regression Kriging, Inverse Distance Weighted and Partial Thin Plate Smoothing Spline. Combining with the sixth National Forest Resources Inventory, we also estimated the forest CSP. The results revealed positive relationships between carbon density of mature forests and temperature, precipitation and stand age, and the horizontal and elevational patterns of carbon density of mature forests can be well predicted by temperature and precipitation. The total CCC and CSP of the existing forests are 19.87 and 13.86 Pg C, respectively. Subtropical forests would have more $C C C$ and CSP than other biomes. Consequently, relying on forests to uptake carbon by decreasing disturbance on forests would be an alternative approach for mitigating greenhouse gas concentration effects besides afforestation and reforestation.
\end{abstract}

carbon carrying capacity, carbon sequestration potential, China, climate, mature forest, pattern, reference level, stand age

Citation: $\quad$ Liu YC, Yu GR, Wang QF, Zhang YJ, Xu ZH. Carbon carry capacity and carbon sequestration potential in China based on an integrated analysis of mature forest biomass. Sci China Life Sci, 2014, 57: 1218-1229, doi: 10.1007/s11427-014-4776-1

Global forests play an important role as carbon sinks in terrestrial ecosystems [1], and will have a huge carbon sequestration potential $(C S P)$ for a period in the future [2]. Thus, the forest carbon sink is considered as a useful option for mitigating climate change [3]. The United Nations Climate Change Conference (UNFCCC) made seven decisions relating to forests in 2013, named "Warsaw Framework for
REDD Plus ${ }^{1) \text { ", }}$ which further confirmed the important role played by forests in offsetting industrial emission of greenhouse gases. Chinese forests store $55 \%$ of the terrestrial ecosystem vegetation carbon (biomass of living trees, excluding shrubs and grasses) [4]. However, the forest carbon density (carbon stock per unit area) in China is about $52 \mathrm{Mg}$ $\mathrm{C} \mathrm{hm}^{-2}$, lower than that of global forests [4]. By 2008, the

*Corresponding author (email: yugr@igsnrr.ac.cn)

1) REDD+ refers to decision 1/CP.16 in the Cancun Agreement that describes REDD+ as "reducing emissions from deforestation and forest degradation, sustainable management of forests, conservation and enhancement of forest carbon stocks". 
potential increase in forest area through afforestation and reforestation is $90 \mathrm{Mhm}^{2}$ [5], and the area of young and middle age-group forests accounts for $67 \%$ of the total forested area [6]. Therefore, Chinese forests will also have a large $C S P$.

To assess the forest CSP, we need to calculate carbon density of the existing forests and then compare that to the reference level of forest carbon density in the future. Based on the approach used in determining the reference level, the methods of assessing the CSP can be classified into four types: Long-Term Continuous Forest Inventory, Space-forTime, Comprehensive Analysis of Environmental Limiting Factors, and Scenario Analysis or Projection Program and Planning Analysis [7]. The long-Term Continuous Forest Inventory method can determine the relationship between carbon density and stand age, and this relationship can be used to predict the carbon density in the future. The Space-for-Time method uses carbon density of mature forests as the reference level of max carbon density [8-10] (i.e., carbon carrying capacity $(C C C)$ ). The Comprehensive Analysis of Environmental Limiting Factors method determines a stage of forest development when the carbon exchange between forests and atmosphere achieves a neutral state, which is determined by radiation, temperature and precipitation, and this method takes the carbon density of forests in this stage as $C C C[11,12]$. The Scenario Analysis, on the basis of the above three methods, integrates species composition, magnitude and frequency of disturbance, human activity (e.g., afforestation and deforestation) and climate change etc. to determine the reference level of $C C C$ and forest area [12-15].

We used the Space-for-Time to assess the CCC and CSP of forests in China. Because the Long-Term Continuous Forest Inventory method requires a longer time than the period our first and last inventories covers [16-18], and the applicability of the Comprehensive Analysis of Environmental Limiting Factors method is limited by the amount of study sites $[19,20]$ and climate change [21,22], these two methods are inappropriate [23]. The Scenario Analysis based on the above two methods is also difficult to apply. The Space-for-Time is based on the climax theory, which hypothesizes that the exiting ecosystem under similar climate would finally reach a climax status by succession [24]. If forest development can be divided into young and mature stages, then carbon density of mature forests can be regarded as the reference level of $C C C$ for the forests under similar climate $[2,25]$. In the paper, we took carbon density of mature forests (a total of 338 sites) as the reference level, and used the interpolated climate dataset to extrapolate carbon density from a site to a regional scale before assessing $C C C$. We used National Forest Resources Inventory to calculate the carbon stock of existing forests and finally assessed forest CSP in China.

\section{Materials and methods}

\subsection{Data}

We used Forest Biomass Site data, the sixth Chinese National Forest Resources Inventory data, Chinese Climate data, Chinese Digital Elevation Model (DEM) data, Chinese Vegetation Map data, and Carbon Carrying Capacity data of Above-ground Biomass in Global Forests.

(i) The Forest Biomass Site data, totally 5841 sites located in China and the surrounding countries (Russia, Mongolia, Indonesia, Malaysia, etc.), were collected from our field work in 2006, 2007 and 2010, permanent-plots of Chinese Ecosystem Network and published papers. From the 5841 sites, 371 with forests aged 80 years or older were extracted and they were treated as Mature Forest sites of China and Surrounding Countries. The 338 of the 371 sites in China were named Mature Forests sites of China (Figure 1).

The age threshold of mature forests is a long debated topic. For planted forests composed of one single species, when we only estimate their above-ground biomass, and neglect effects of succession and climate change, an age threshold value of 80-100 years is conventionally assumed. For forests with complex species composition, when we evaluate the ecosystem carbon pool and consider effects of succession and climate change, the age threshold should be much higher than 100 years. Also, the age thresholds of mature forests vary with biome types [26]. In this study, we used the age threshold of 80 years. On one hand, the age threshold of mature forests is conventionally regarded as 80-100 years [25,27,28], and most tree species in China have reached economically mature stage at or before 80 years. The 80-year threshold can meet the requirement of conservatively assessing forest carbon sink. On the other hand, this study is constrained by data availability. Generally, data on older forests is relatively in shortage [2].

All the forest site data were compiled from field data of one or more plots. The field data collection procedure is composed of: sampling design, plot and subplots setting up, diameter at breast height and tree height measurement, shrubs and grasses measuring and sampling, litter and dead woody debris sampling, soil bulk density and soil organic carbon measuring and sampling, indoor measurement and data analysis [10].

Forest biomass was calculated using three methods: (a) biomass of each tree was calculated using the species specific allometric equations, then the value of each tree was summed before being converted to biomass per unit area [10]; (b) the trunk volume of each tree was calculated using the species specific timber tables or equations, then they were converted to biomass per unit area by multiplying biomass-volume conversion and expansion, and then were summed [29]; (c) the biomass of a sampling tree with mean diameter at breast height was calculated using the allometric 


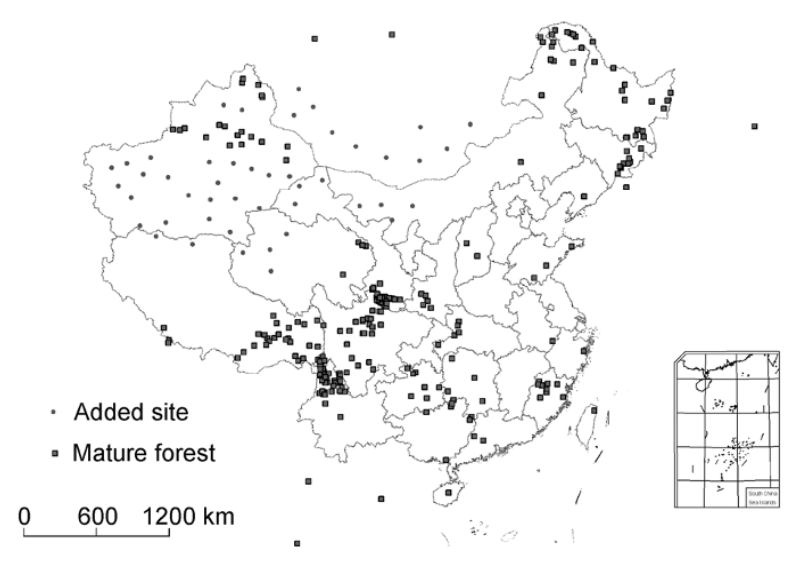

Figure 1 The distribution of mature forests in China and neighboring countries. Added sites are those sites with carbon density of $0 \mathrm{Mg} \mathrm{C} \mathrm{hm}{ }^{-2}$ (circle); mature forest denotes the mature forest site (square).

equations, then they were converted to biomass per unit area by multiplying tree density [30].

The stand ages of forest sites were mainly collected from literature search, which were determined using tree-ring counting, historical records of afforestation and radiocarbon dating. For the forests in China, the stand ages are based on the tree-ring counting and the historical records of afforestation. For our measured sites, the forest stand ages were based on the tree-ring counting [26]. Climate data of each research site was mostly obtained by literature search. For the sites without climate data, the missing part was extracted from Chinese Climate according to their geological coordinates as noted in the original papers.

(ii) The sixth National Forest Resources Inventory was conducted by the State Forestry Administration during the period of 1999-2003. Based on sampling theory and a total of $4.15 \times 10^{5}$ permanent and temporary plots, the National Forest Resources Inventory provides growing stock volume data of 48 forest types for all the provinces of China except Hong Kong, Macao and Taiwan [31]. Because the National Forest Resources Inventory is more authority than other publicly available data, it has been widely used in assessing carbon stock and carbon sink of Chinese forests [7,32,33].

(iii) Chinese Climate data was provided by Chinese Ecosystem Research Network (CERN) and has information of mean annual temperature and mean annual precipitation over the period of 1980-2000. The dataset has a spatial resolution of $1 \mathrm{~km}$ and was interpolated using more than 700 meteorological stations [34,35].

(iv) Chinese DEM, with a spatial resolution of $30 \mathrm{~m}$, was provided by library of Institute of Geographic Sciences and Natural Resources Research, Chinese Academy of Sciences. It was generated by first being scanned from 1:250000 topographic maps, then was vectorized and georeferenced (Albers, Beijing 1954). The DEM data was used to extract altitude for those sites without elevation information. (v) Chinese Vegetation map is a part of Vegetation Information Management System VIS 3.0, it includes a 1:1 M Vegetation Atlas of China and a Chinese Vegetation zone map, and covers all the terrestrial regions (including Taiwan) of China [36,37].

(vi) The Carbon Carrying Capacity of Above-ground Biomass in Global Forests was generated by Liu et al. [2] using three interpolation methods, including Regression Kriging, Inverse Distance Weighted, and Thin Plate Smoothing Spline, based on Above-ground Biomass of Global Forests [26], Global Climate [38,39] and Global Land Cover 2000 [40]. The data has a spatial resolution of 1 $\mathrm{km}[2]$.

\subsection{Driving factor analysis of the patterns of carbon density of mature forests}

We used linear regression to explore the latitudinal and longitudinal patterns of carbon density of mature forests. We chose four typical mountains to analyze the carbon density pattern along altitude. The four chosen mountains, Wuyi Mountain, Changbai Mountain, Tianshan Mountain and Hengduan Mountain represent the four regions in Southeast, Northeast, Northwest and Southwest, respectively.

We explored the driving effects on carbon density of mature forests using linear regressions. We firstly established the dependencies of carbon density on climate and stand age, and then chose the principle factors based on coefficient determination $\left(R^{2}\right)$ and $F$-test $(P)$. Finally, we used the equation to describe the carbon density of mature forests in the form of curve surface.

\subsection{Assessing carbon carrying capacity and carbon sequestration potential}

The Carbon Sequestration Potential (CSP) is the difference between Carbon Carrying Capacity $(C C C)$ and Carbon Density $(C D)$ of the present forest biomass:

$$
C S P=C C C-C D \text {. }
$$

We calculated the forest carbon density using the method of biomass expansion factor $(B E F)$ [32]. We obtained the coefficients of $B E F$ from literature [33] and did some minor modification [7]:

$$
C D=C F \times B E F \times V,
$$

where $V$ is the growing volume stock for a specific type and certain age group of forests in a province from the sixth National Forest Resources Inventory; $C F$ is the carbon factor of forest biomass and we used 0.5 in this study [23].

We estimated the forest $C C C$ in China using interpolation and employed carbon density of mature forests as the reference level [2]. To avoid the non-neutral results caused by data and method bias, we used two mature forest datasets (Mature Forest Biomass of China and Surrounding Coun- 
tries, and Above-ground Biomass of Global Mature Forests), two climate datasets (Chinese Climate and Global Climate), two forest distribution datasets (Chinese Vegetation and Global Land Cover), three interpolation methods (Regression Kriging, Inverse Distance Weighted, and Thin Plate Smoothing Spline), and proposed six assessment schemes totally. The details are as follows:

Scheme 1: based on carbon density of mature forests and climate in China, we generated an equation to fit the carbon density of mature forests against climatic factors (eq. (3)). Using this equation and Chinese Climate data, a surface trend of mature forest carbon density $(C)$ was simulated based on its relationship with mean annual temperature (Tem) and mean annual precipitation (Pre). Then the regression residuals between the modeled surface trend and observed results were used to produce a residual surface $(\varepsilon)$. The sum of $C$ and $\varepsilon$ is the predicted curve surface of $C C C$ in China. Finally, the forest $C C C$ was extracted from the predicted curve surface for those forest distributed areas from 1:1 M Vegetation Atlas of China.

$$
C C C=C+\varepsilon=f(\text { Tem, Pre })+\varepsilon .
$$

The scheme 2 is similar to the scheme 1 . The difference is that we used forest distribution data from Global Land Cover instead of Vegetation Atlas of China as used in the scheme 1.

The scheme 3 has similar steps to the scheme 1 . The only difference is that the scheme 3 used the Above-ground Biomass of Global Mature Forests to establish the relationship between above-ground biomass carbon density and climate, and then obtained $C C C$ of above-ground biomass of global forests based on Global Climate and Global Land Cover.

The scheme 4 is based on Mature Forest Biomass of China and Surrounding Countries. We used interpolation of Inverse Distance Weighted to scale up the carbon density from a site to the country, and used forest distribution data from Vegetation Atlas of China to extract the forest distrib- uted areas. To improve the accuracies of the interpolation results, we added several forest-free sites with zero carbon density where mean annual precipitation is less than $370 \mathrm{~mm}$ (Figure 1).

The scheme 5 uses the same data as the scheme 3 . The only difference is that we used the interpolation of Thin Plate Smoothing Spline in the scheme 5 to analyze the $C C C$ pattern of the above-ground biomass in global forests.

The scheme 6 is similar to the scheme 4 , but is based on the Above-ground Biomass of Global Mature Forests and the result represents $C C C$ of above-ground biomass in global forests.

The details of the schemes 3, 5 and 6 can be seen in Liu et al. [2]. Here, we extracted the $C C C$ of the above-ground biomass in Chinese forests from the results of these three schemes.

\section{Results}

\subsection{Horizontal patterns of carbon density of mature forests}

We explored the horizontal patterns of carbon density of mature forests in China in both latitudinal and longitudinal directions. Along latitude, the carbon density mainly decreases from low-mid latitudes $\left(20-30^{\circ} \mathrm{N}\right)$ to high latitudes $\left(50^{\circ} \mathrm{N}\right)$, similar to that of the global mature forests, with a declining rate of $-5.8473 \mathrm{Mg} \mathrm{C} \mathrm{hm}^{-2} \mathrm{deg}^{-1}$ (Figure 2A). The low boundary of carbon density is close among the sites from low to high latitudes, but the upper boundary in low latitudes is much higher than that in high latitudes. In addition, there are two regions with low carbon density located in mid-latitude $\left(38^{\circ} \mathrm{N}\right)$ and high-latitude $\left(50^{\circ} \mathrm{N}\right)$, respectively. Along longitude, the carbon density has no obvious pattern at a national scale, but an increasing trend exists in some regions, for example, in Northeast China $\left(120^{\circ} \mathrm{E}\right.$ and east) (Figure 2B).
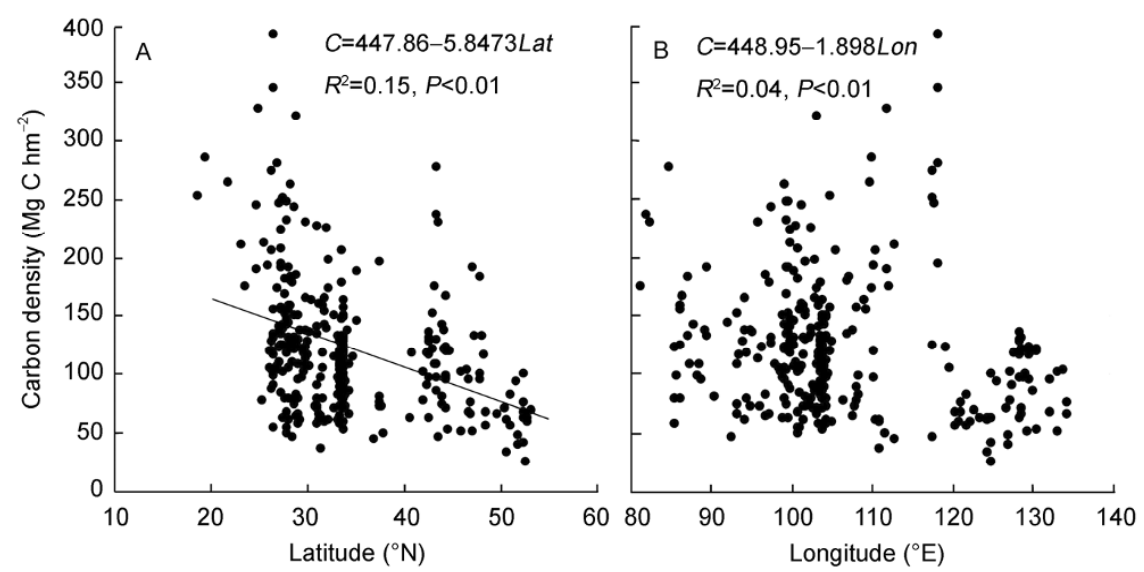

Figure 2 Latitudinal (A) and longitudinal (B) patterns of carbon density of mature forests. In regression equations, $C$ is carbon density, Mg C hm ${ }^{-2}$; Lat is latitude, ${ }^{\circ} \mathrm{N}$; Lon is longitude, ${ }^{\circ} \mathrm{E}$. 


\subsection{Elevational patterns of carbon density of mature forests}

The elevational patterns of carbon density of mature forests varied among the four typical mountains. Wuyi Mountain and Changbai Mountain are located in the east of China. The mature forest distributed altitude is $0-1300 \mathrm{~m}$ for the former and 800-1900 $\mathrm{m}$ for the latter. The two mountains are located in different regions of China, but their carbon densities both decrease with increasing elevation. The carbon density declines linearly on Wuyi Mountain from 393 $\mathrm{Mg} \mathrm{C} \mathrm{hm}^{-2}$ near sea level to $126 \mathrm{Mg} \mathrm{C} \mathrm{hm}^{-2}$ around $1300 \mathrm{~m}$. The carbon density declines gradually on Changbai Mountain from 133 to $2 \mathrm{Mg} \mathrm{C} \mathrm{hm}^{-2}$ as elevation increases from 800 to $1900 \mathrm{~m}$ (Figure 3).

Tianshan Mountain and Hengduan Mountain are located in the west of China, and the forest distributed elevations of these two mountains are higher than in Wuyi and Changbai Mountain. The altitude of mature forests on Tianshan Mountain is lower and distributed range is narrower $(1800-2500 \mathrm{~m})$ than that on Hengduan Mountain (2500-4300 m). For mature forests on Tianshan Mountain, the carbon density declines from 279 to $75 \mathrm{Mg} \mathrm{C} \mathrm{hm}^{-2}$ as elevation increases from 1800 to $2100 \mathrm{~m}$, then increases to $238 \mathrm{Mg} \mathrm{C} \mathrm{hm}^{-2}$ as elevation increases from 2100 to $2500 \mathrm{~m}$ (Figure 3). For mature forests on Hengduan Mountain, the carbon density increases from 100 to $275 \mathrm{Mg} \mathrm{C} \mathrm{hm}^{-2}$ as elevation increases from 2500 to $3800 \mathrm{~m}$, and decreases from 275 to $80 \mathrm{Mg} \mathrm{C} \mathrm{hm}^{-2}$ as elevation increases from 3800 to $4300 \mathrm{~m}$ (Figure 3 ).

\subsection{Control of temperature, precipitation and stand age on carbon density of mature forests}

Figure 4 shows the relationship between carbon density of mature forests and mean annual temperature and mean annual precipitation in China. Most of the mature forests are

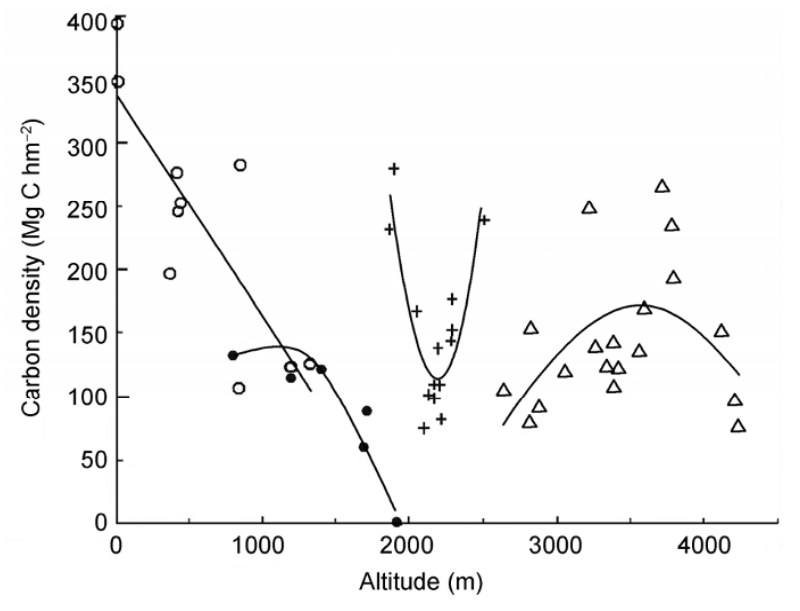

Figure 3 Patterns of carbon density of mature forests along rising elevation. Wuyi Mountain in Fujian (open circle o), Changbai Mountain in Jilin (solid circle/black ball •), Tianshan Mountain in Xinjiang (plus +) and Hengduan Mountain in Yunnan (triangle $\triangle$ ).

located in regions with mean annual temperature -6 to $20^{\circ} \mathrm{C}$ (Figure 4A) and mean annual precipitation 370-2000 mm. This $370 \mathrm{~mm}$ (dashed line in Figure 4B) is close to the value of $400 \mathrm{~mm}$, which is considered as the grass-forest boundary. Figure 4 shows the positive relationships between mean carbon density and mean annual temperature and mean annual precipitation $(P<0.01)$, and the range of carbon density increases with increasing temperature and precipitation. When mean annual temperature is -5 to $20^{\circ} \mathrm{C}$, the increasing rate of carbon density is $10.15 \mathrm{Mg} \mathrm{C} \mathrm{hm}^{-2}{ }^{\circ} \mathrm{C}^{-1}$; when mean annual precipitation is $370-2500 \mathrm{~mm}$, the increasing rate of carbon density is $0.144 \mathrm{Mg} \mathrm{C} \mathrm{hm}^{-2} \mathrm{~mm}^{-1}$. The range of carbon density increases from 50 to $300 \mathrm{Mg} \mathrm{C} \mathrm{hm}^{-2}$ as temperature increases from -5 to $10^{\circ} \mathrm{C}$, and increases from 150 to $300 \mathrm{Mg} \mathrm{C} \mathrm{hm}^{-2}$ as precipitation increases from 370 to $1700 \mathrm{~mm}$.

Figure 5 shows a positive relationship between carbon
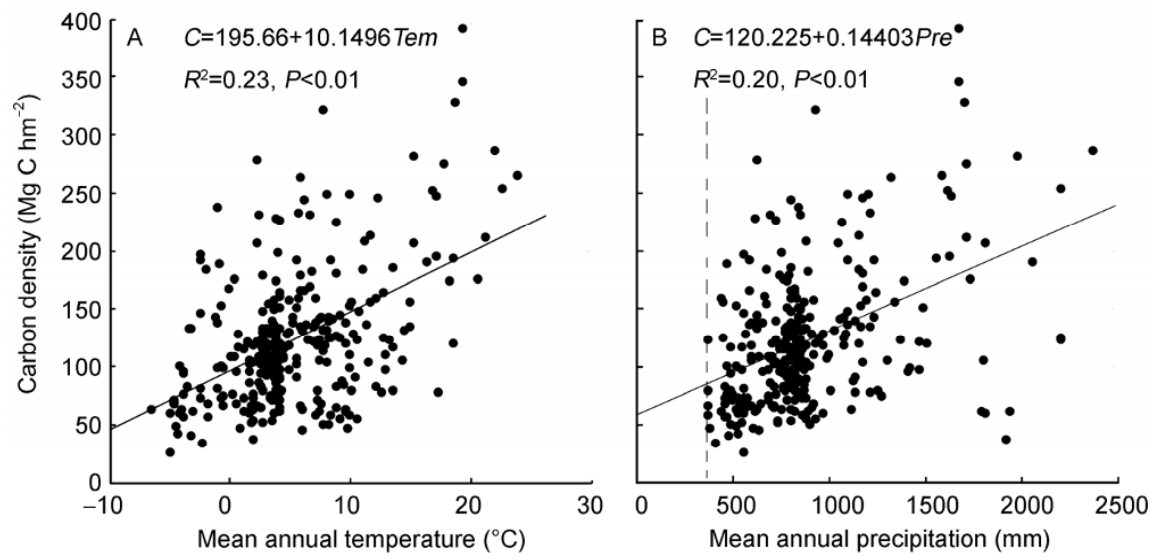

Figure 4 Carbon density of mature forests in relation to mean annual temperature (A) and mean annual precipitation (B). The solid lines are regressions between carbon density and climatic factors; the dashed line is the boundary of $370 \mathrm{~mm}$ of mean annual precipitation. In the regression equations, $C$ is carbon density, $\mathrm{Mg} \mathrm{C} \mathrm{hm}^{-2}$; Tem is mean annual temperature, ${ }^{\circ} \mathrm{C}$; Pre is mean annual precipitation, $\mathrm{mm}$. 


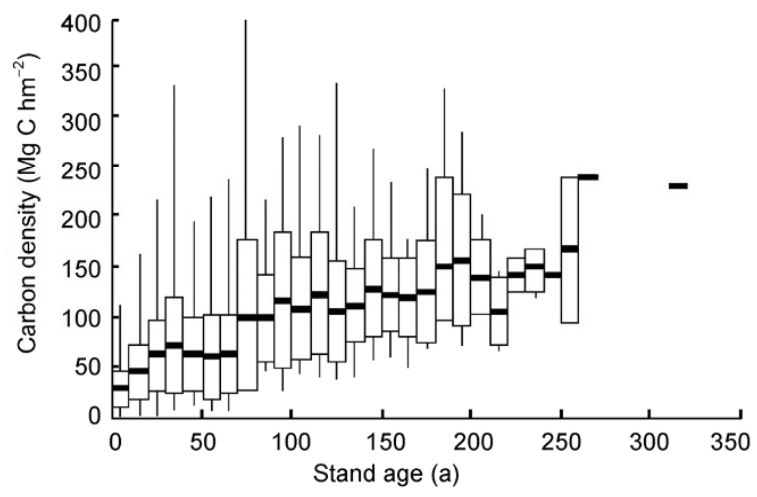

Figure 5 The relationship between carbon density and stand age for Chinese forests. The mean (the horizontal bold line), standard deviation (the box), minimum and maximum (the vertical thin line) carbon density of forests with every 10-year bands.

density and forest stand age. When the stand age is between 3 and 200 years, the increasing rate of carbon density is $0.65 \mathrm{Mg} \mathrm{C} \mathrm{hm}^{-2} \mathrm{a}^{-1}$. However, the increasing rate follows a declining trend for forests older than 100 years. For example, for the forests with stand age of 3-50, 50-100 and 100-200 years, the increasing rates are about $1.23,1.31$ and $0.35 \mathrm{Mg} \mathrm{C} \mathrm{hm} \mathrm{a}^{-1}$, respectively. The increasing rate of carbon density is different between planted and natural forests. When the forests are 80 years or younger, the increasing rates of carbon density of planted forests are higher than that of natural forests, with values of 2.60 and $1.27 \mathrm{Mg} \mathrm{C}$ $\mathrm{hm}^{-2} \mathrm{a}^{-1}$, respectively. In addition, both planted and natural forests with the highest carbon density have the highest stand age. For example, the carbon density of a natural forest at Bomi in Tibet is $750 \mathrm{Mg} \mathrm{C} \mathrm{hm}^{-2}$ and it has a stand age over 350 years; and a planted forest in Nanping, Fujian Province has a carbon density of $370 \mathrm{Mg} \mathrm{C} \mathrm{hm}^{-2}$ and it is 80 years old.

As Table 1 shows, using temperature, precipitation and
Table 1 The carbon density in relation to precipitation, temperature and stand age for the mature forests in China

\begin{tabular}{ccccc}
\hline $\mathrm{N}$ & Equation $^{\text {a) }}$ & $R^{2}$ & $P$ & $n$ \\
\hline 1 & $C=7.25+0.0349$ Pre+4.4900Tem & 0.37 & $<0.01$ & 308 \\
2 & $\quad$ +0.4793Age & & & \\
3 & $C=74.52+0.0352$ Pre +3.5474 Tem & 0.26 & $<0.01$ & 318 \\
4 & $C=2.23+6.0028$ Tem+0.4805Age & 0.34 & $<0.01$ & 308 \\
\end{tabular}

a) $C$ is carbon density of mature forest, $\mathrm{Mg} \mathrm{C} \mathrm{hm}^{-2}$; Pre is mean annual precipitation, mm; Tem is mean annual temperature, ${ }^{\circ} \mathrm{C}$; Age is stand age, a.

stand age as independent variables to predict carbon density of mature forests, the equation is statistically significant $\left(R^{2}=0.37, P<0.01\right)$. Using two of the three factors as independent variables, the regression equations are also statistically significant $(P<0.01)$. Among the equations, temperature and stand age can explain carbon density better than the others $\left(R^{2}=0.34, P<0.01\right)$, followed by precipitation and stand age $\left(R^{2}=0.27, P<0.01\right)$, the last one is the equation with variables of temperature and precipitation $\left(R^{2}=0.26\right.$, $P<0.01)$.

\subsection{Carbon carrying capacity and carbon sequestra- tion potential of Chinese forests}

Based on the data availability and the relationships between carbon density and driving factors, we chose eq. (4) as our carbon density-climate regression model, and used scheme 1 to generate the $C C C$ in Chinese forests (Figure 6A), with an output of 19.9 Pg C (Table 2).

$$
C=74.52+0.0352 \text { Pre }+3.5474 \text { Tem }+\varepsilon \text {. }
$$

Based on the scheme 2, the biomass $C C C$ in Chinese forests is $28.3 \mathrm{Pg} \mathrm{C}$. Based on the scheme 4, the biomass $C C C$ is 27.6 Pg C using the Inverse Distance Weighted interpolation (Figure 6B). The mean $C C C$ of above-ground biomass in Chinese forests is $26.4 \mathrm{Pg}$ when averaged on the results

Table 2 Carbon carrying capacity of forests in China under the six schemes

\begin{tabular}{|c|c|c|c|c|c|}
\hline Scheme & Method & Carbon pool & Data & $\begin{array}{c}\text { Total carbon carrying } \\
\text { capacity }(\mathrm{Pg} \mathrm{C})^{\mathrm{a})}\end{array}$ & Ref. \\
\hline 1 & $\begin{array}{l}\text { Biomass carbon density- } \\
\text { climate Regression Kriging }\end{array}$ & Biomass of forests in China & $\begin{array}{c}\text { Mature Forest Biomass of China, } \\
\text { Chinese Climate, and Vegetation } \\
\text { Atlas of China }\end{array}$ & 19.9 & This study \\
\hline 2 & $\begin{array}{l}\text { Biomass carbon density- } \\
\text { climate Regression Kriging }\end{array}$ & Biomass of forests in China & $\begin{array}{c}\text { Mature Forest Biomass of China, } \\
\text { Chinese Climate, and Global Land } \\
\text { Cover } 2000\end{array}$ & 28.3 & This study \\
\hline 3 & $\begin{array}{l}\text { Above-ground biomass car- } \\
\text { bon density-climate Regres- } \\
\text { sion Kriging }\end{array}$ & $\begin{array}{l}\text { Above-ground biomass of } \\
\text { forests in China }\end{array}$ & $\begin{array}{c}\text { Above-ground Biomass of Global } \\
\text { Forests, Global Climate, and Global } \\
\text { Land Cover } 2000\end{array}$ & 27.6 & {$[2]$} \\
\hline 4 & Inverse Distance Weighted & Biomass of forests in China & $\begin{array}{c}\text { Mature Forest Biomass of China and } \\
\text { Surrounding Countries, and Global } \\
\text { Land Cover } 2000\end{array}$ & 27.6 & This study \\
\hline 5 & $\begin{array}{l}\text { Partial Thin Plate Smoothing } \\
\text { Spline }\end{array}$ & $\begin{array}{l}\text { Above-ground biomass of } \\
\text { forests in China }\end{array}$ & $\begin{array}{l}\text { Above-ground Biomass of Global } \\
\text { Forests, Global Climate, and Global } \\
\text { Land Cover } 2000\end{array}$ & 28.5 & {$[2]$} \\
\hline \multirow[t]{2}{*}{6} & Inverse Distance Weighted & $\begin{array}{l}\text { Above-ground biomass of } \\
\text { forests in China }\end{array}$ & $\begin{array}{c}\text { Above-ground Biomass of Global } \\
\text { Forests, and Global Land Cover } 2000\end{array}$ & 23.0 & {$[2]$} \\
\hline & Mean of scheme $3,5,6$ & & & 26.4 & \\
\hline
\end{tabular}

a) A petagram $(\mathrm{Pg})$ is $10^{15} \mathrm{~g}$. 

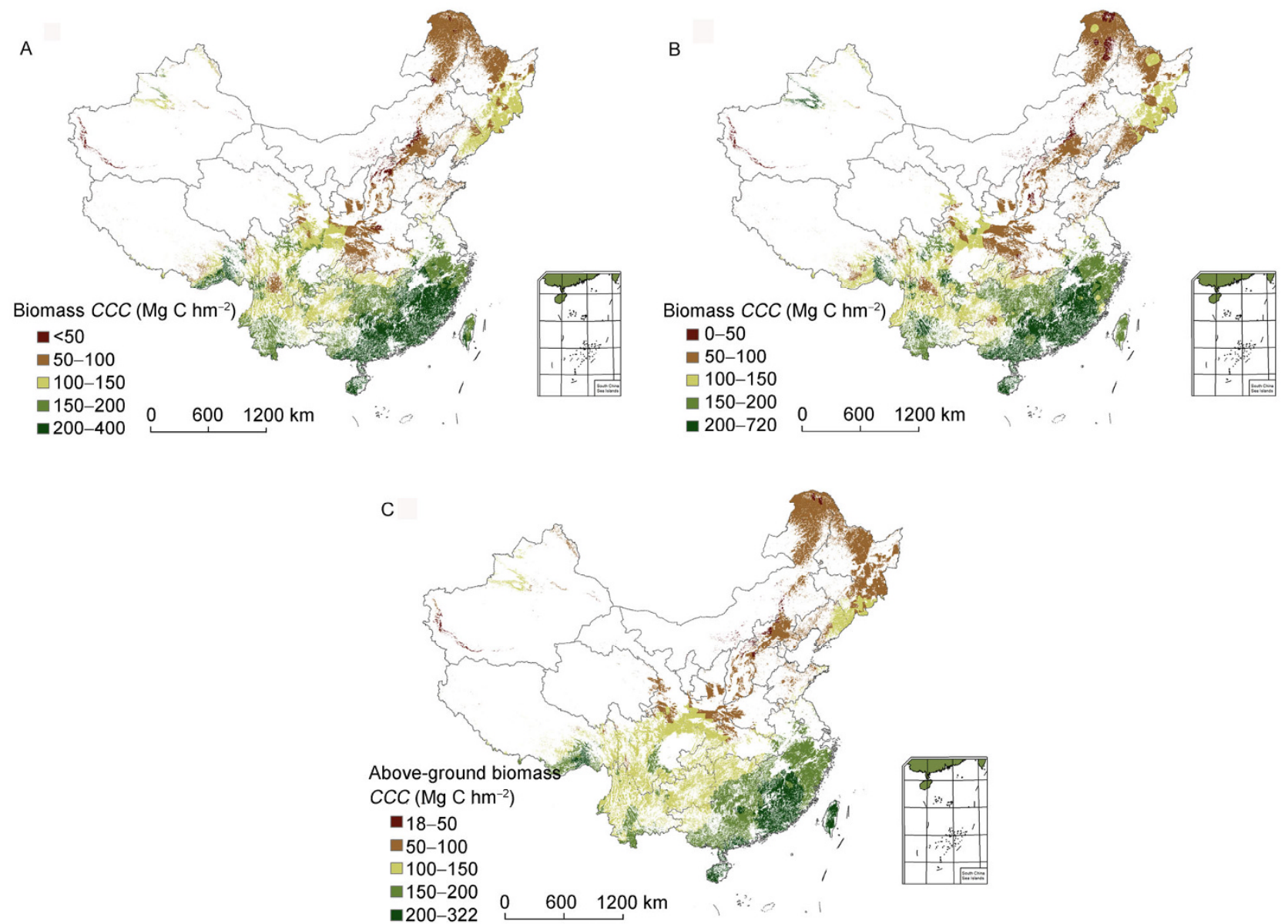

Figure 6 The carbon carrying capacity $(C C C)$ of Chinese forests by different interpolations. A, Biomass carbon density-climate Regression Kriging. B, Inverse Distance Weighted based on Chinese mature forests. C, Three interpolations of Regression Kriging, Inverse Distance Weighted, and Thin Plate Smoothing Spline based on global mature forests.

from the scheme 3, 5 and 6 (Figure 6C). If the ratio of the above-ground biomass to biomass (above- and blow-ground biomass) is 0.8 [26], the biomass $C C C$ in Chinese forests is 34.5, 35.6 and 28.8 Pg C for the scheme 3, 5 and 6, respectively, higher than the results based on the Chinese mature forests and Chinese Climate.

Figure 6 shows the spatial patterns of $C C C$ in Chinese forests. Although the six schemes based on different data and interpolation methods produced different results, the spatial patterns are similar among these schemes. The $C C C$ has a declining trend from South to North, from East to West, and from Southeast to Northwest. Based on all statistic results of the six schemes, assuming that the existing forests would grow naturally to mature forests and taking no account of reforestation, the $C C C$ would be between 19.9 and 27.6 Pg C.

Table 3 illustrates the forest $C C C$ in each ecological zone. Specifically, the subtropical evergreen broadleaf forests have higher $C C C$ and total $C C C$ than other biomes. The $C C C$ and total $C C C$ is $167.4 \mathrm{Mg} \mathrm{C} \mathrm{hm}^{-2}$ and $13.32 \mathrm{Pg} \mathrm{C}$, respectively. The total $C C C$ of the subtropical evergreen broadleaf forests accounts for $67.0 \%$ of that in Chinese forests. The second is temperate needleleaf and deciduous broadleaf forests, which have a total CCC of $2.18 \mathrm{Pg} \mathrm{C}$ and account for $11.0 \%$ of that in Chinese forests. The third is tropical monsoon and rain forests, which have a total $C C C$ of $1.56 \mathrm{Pg} \mathrm{C}$ and account for $7.9 \%$ of that in Chinese forests. The following sequentially ranked are warm temperate deciduous broadleaf forests, cold temperate needleleaf forests, temperate steppe, temperate desert, and Qinghai-Xizang (Tibetan) plateau high-cold vegetation. The forests in these five ecological zones have a total $C C C$ of $2.81 \mathrm{Pg} \mathrm{C}$ and account for $14.1 \%$ of that in Chinese forests.

Table 4 illustrates the carbon stock, $C C C$ and $C S P$ of Chinese forests in each region and province. At a regional scale, the carbon stock of Southwest and Northeast China (about 2.326 and 1.429 Pg C and accounting for $38.7 \%$ and $23.8 \%$ of the total, respectively) is higher than in other regions (accounting for $37.5 \%$ of the total). The CCC of South, Southeast and Central China (about 208.5, 207.0 and $160.9 \mathrm{Mg} \mathrm{C} \mathrm{hm}^{-2}$, respectively) is higher than in other regions. The $C C C$ of North and Northeast China is low, less 
Table 3 The forest carbon carrying capacity by ecological zone ${ }^{a)}$

\begin{tabular}{|c|c|c|c|c|c|c|c|}
\hline \multirow{2}{*}{ Ecological zone } & \multicolumn{4}{|c|}{ Carbon carrying capacity $\left(\mathrm{Mg} \mathrm{C} \mathrm{hm}^{-2}\right)$} & \multirow{2}{*}{$\begin{array}{l}\text { Forest area } \\
\left(10^{4} \mathrm{~km}^{2}\right)\end{array}$} & \multicolumn{2}{|c|}{$\begin{array}{c}\text { Total carbon carrying } \\
\text { capacity }\end{array}$} \\
\hline & Mean & Min & Max & STD & & $\mathrm{PgC}$ & $\%$ \\
\hline Cold temperate needleleaf forest & 64.2 & 27.4 & 117.9 & 13.5 & 13.7 & 0.88 & 4.4 \\
\hline Warm temperate deciduous broadleaf forest & 79.3 & 39.9 & 143.5 & 20.6 & 12.0 & 0.95 & 4.8 \\
\hline Temperate steppe & 66.8 & 5.2 & 174.2 & 25.6 & 9.7 & 0.65 & 3.3 \\
\hline Temperate desert & 106.7 & 0.0 & 279.3 & 79.9 & 2.5 & 0.26 & 1.3 \\
\hline Temperate needleleaf and deciduous broadleaf forest & 93.9 & 52.4 & 149.0 & 15.9 & 23.2 & 2.18 & 11.0 \\
\hline Subtropical evergreen broadleaf forest & 167.4 & 39.7 & 538.9 & 58.6 & 79.6 & 13.32 & 67.0 \\
\hline Qinghai-Xizang (Tibetan) plateau high-cold vegetation & 131.4 & 39.6 & 181.3 & 40.2 & 0.5 & 0.06 & 0.3 \\
\hline Tropical monsoon forest and rain forest & 153.0 & 78.5 & 286.4 & 57.6 & 10.2 & 1.56 & 7.9 \\
\hline Total & & & & & 151.4 & 19.87 & 100.0 \\
\hline
\end{tabular}

a) The table results were calculated using the scheme 1. The ecological zone and forest distribution data were both from the Chinese Vegetation Zone map and Vegetation Atlas of China [36,37].

Table 4 Carbon stock, carbon carrying capacity and carbon sequestration potential of forests at provincial and regional scales ${ }^{\text {a) }}$

\begin{tabular}{|c|c|c|c|c|c|c|c|c|}
\hline \multirow{2}{*}{ Region } & \multirow{2}{*}{ Province } & \multicolumn{2}{|c|}{ Carbon stock } & \multicolumn{3}{|c|}{ Carbon carrying capacity } & \multicolumn{2}{|c|}{ Carbon sequestration potential } \\
\hline & & $\mathrm{Pg} \mathrm{C}$ & $\%$ & $\mathrm{Mg} \mathrm{C} \mathrm{hm}^{-2}$ & Total, Pg C & $\%$ & $\mathrm{Pg} \mathrm{C}$ & $\%$ \\
\hline \multirow[b]{6}{*}{ North China } & Beijing & 0.006 & 0.1 & 63.5 & 0.004 & & - b) & \\
\hline & Tianjin & 0.001 & - & 68.2 & 0.001 & & $-{ }^{\mathrm{b})}$ & \\
\hline & Hebei & 0.046 & 0.8 & 60.8 & 0.088 & 0.4 & 0.042 & 0.3 \\
\hline & Shanxi & 0.037 & 0.6 & 51.1 & 0.099 & 0.5 & 0.063 & 0.5 \\
\hline & Inner Mongolia & 0.579 & 9.6 & 61.4 & 0.959 & 4.8 & 0.380 & 2.7 \\
\hline & & 0.669 & 11.1 & 60.3 & 1.151 & 5.8 & $\sim 0.485^{\text {a) }}$ & \\
\hline \multirow[b]{4}{*}{ Northeast China } & Liaoning & 0.117 & 1.9 & 82.1 & 0.351 & 1.8 & 0.234 & 1.7 \\
\hline & Jilin & 0.472 & 7.9 & 105.1 & 0.808 & 4.1 & 0.336 & 2.4 \\
\hline & Heilongjiang & 0.840 & 14.0 & 81.2 & 1.656 & 8.3 & 0.816 & 5.9 \\
\hline & & 1.429 & 23.8 & 87.0 & 2.815 & 14.2 & 1.388 & 10.0 \\
\hline \multirow[b]{7}{*}{ East China } & Shanghai & - & & - & - & & - & \\
\hline & Jiangsu & 0.012 & 0.2 & 158.6 & 0.035 & 0.2 & 0.023 & 0.2 \\
\hline & Zhejiang & 0.052 & 0.9 & 193.6 & 0.975 & 4.9 & 0.923 & 6.7 \\
\hline & Anhui & 0.058 & 1.0 & 185.5 & 0.405 & 2.0 & 0.347 & 2.5 \\
\hline & Fujian & 0.183 & 3.0 & 250.3 & 1.952 & 9.8 & 1.769 & 12.8 \\
\hline & Shandong & 0.021 & 0.3 & 96.4 & 0.186 & 0.9 & 0.165 & 1.2 \\
\hline & & 0.326 & 5.4 & 207.0 & 3.553 & 17.9 & 3.227 & 23.3 \\
\hline \multirow[b]{5}{*}{ Central China } & Henan & 0.057 & 0.9 & 67.2 & 0.174 & 0.9 & 0.117 & 0.8 \\
\hline & Hubei & 0.094 & 1.6 & 82.1 & 0.248 & 1.2 & 0.154 & 1.1 \\
\hline & Hunan & 0.126 & 2.1 & 173.5 & 1.56 & 7.8 & 1.434 & 10.3 \\
\hline & Jiangxi & 0.153 & 2.5 & 221.7 & 1.339 & 6.7 & 1.186 & 8.6 \\
\hline & & 0.430 & 7.2 & 160.9 & 3.321 & 16.7 & 2.891 & 20.9 \\
\hline \multirow[b]{4}{*}{ South China } & Guangdong & 0.169 & & 224.6 & 0.817 & 4.1 & 0.648 & 4.7 \\
\hline & Guangxi & 0.199 & & 192.5 & 1.317 & 6.6 & 1.118 & 8.1 \\
\hline & Hainan & 0.053 & & 281 & 0.197 & 1.0 & 0.144 & 1.0 \\
\hline & & 0.421 & 7.0 & 208.5 & 2.331 & 11.7 & 1.91 & 13.8 \\
\hline \multirow[b]{6}{*}{ Southwest China } & Sichuan & 0.631 & 10.5 & 132.7 & 1.645 & 8.3 & 1.014 & 7.3 \\
\hline & Yunnan & 0.730 & 12.1 & 159.4 & 1.631 & 8.2 & 0.901 & 6.5 \\
\hline & Guizhou & 0.088 & 1.5 & 140.5 & 0.539 & 2.7 & 0.451 & 3.3 \\
\hline & Tibet & 0.839 & 14.0 & 122.9 & 1.237 & 6.2 & 0.398 & 2.9 \\
\hline & Chongqing & 0.038 & 0.6 & 122.6 & 0.132 & 0.7 & 0.094 & 0.7 \\
\hline & & 2.326 & 38.7 & 137.8 & 5.184 & 26.1 & 2.858 & 20.6 \\
\hline \multirow[b]{6}{*}{ Northwest China } & Shaanxi & 0.188 & 3.1 & 90.7 & 0.448 & 2.3 & 0.26 & 1.9 \\
\hline & Gansu & 0.090 & 1.5 & 114.6 & 0.403 & 2.0 & 0.313 & 2.3 \\
\hline & Qinghai & 0.015 & 0.2 & 109.7 & 0.083 & 0.4 & 0.068 & 0.5 \\
\hline & Ningxia & 0.003 & 0.0 & 74.4 & 0.006 & & 0.003 & 0.0 \\
\hline & Xinjiang & 0.112 & & 118.5 & 0.317 & 1.6 & 0.205 & 1.5 \\
\hline & & 0.408 & 6.8 & 105.0 & 1.257 & 6.3 & 0.849 & 6.1 \\
\hline \multirow{4}{*}{$\begin{array}{c}\text { Hong Kong, } \\
\text { Macau, Taiwan }\end{array}$} & Hong Kong & - & & 215.3 & 0.003 & & - & \\
\hline & Macau & - & & 214.1 & 0.001 & & - & \\
\hline & Taiwan & - & & 182.2 & 0.257 & 1.3 & - & \\
\hline & & & & 182.6 & 0.261 & 1.3 & - & \\
\hline China & & 6.009 & 100.0 & 131.2 & 19.873 & 100.0 & $\sim 13.864^{\text {c) }}$ & 100.0 \\
\hline
\end{tabular}

a) The table results are from the scheme 1. b) For Beijing and Tianjin, the interpolated results of carbon density of mature forests may be too conservative, because no mature forest dataset is available for these areas. c) We provided an approximate value of forest CSP due to no forest carbon stock data available for Hong Kong, Macau and Taiwan. 
than $100 \mathrm{Mg} \mathrm{C} \mathrm{hm}^{-2}$. The Southwest, East and Central China have higher total $C C C$ than in other regions, with values of about 5.184, 3.553 and $3.321 \mathrm{Pg} \mathrm{C}$ and accounting for $26.1 \%, 17.9 \%$ and $16.7 \%$ of the total, respectively.

At a provincial scale, Heilongjiang, Tibet and Yunnan have higher forest carbon stock than in other provinces, with values of about $0.840,0.839$ and $0.730 \mathrm{Pg} \mathrm{C}$ and accounting for $14.0 \%, 14.0 \%$ and $12.1 \%$ of the total, respectively. The CCC of Hainan and Fujian is over $250 \mathrm{Mg} \mathrm{C}$ $\mathrm{hm}^{-2}$, higher than the other provinces. The $C C C$ of Fujian, Heilongjiang, Sichuan and Yunnan is the highest, with values of 1.952, 1.656, 1.645 and $1.631 \mathrm{Pg} \mathrm{C}$ and accounting for $9.8 \%, 8.3 \%, 8.3 \%$ and $8.2 \%$ of the total, respectively (Table 4).

For $C S P$ at a regional scale, East, Central and Southwest China have higher CSP than the other five regions, with values of 3.227, 2.891 and $2.858 \mathrm{Pg} \mathrm{C}$, and accounting for $23.3 \%, 20.9 \%$ and $20.6 \%$ of the total, respectively. At a provincial scale, Fujian, Hunan and Guangxi have higher CSP than the other provinces, with values of about 1.769 , 1.434 and $1.118 \mathrm{Pg} \mathrm{C}$, and accounting for $12.8 \%, 10.3 \%$ and $8.1 \%$ of the total, respectively.

\section{Discussion}

\subsection{Climate control on the horizontal patterns of car- bon density of mature forests}

The mature forests in China followed obvious horizontal patterns by forest types and carbon density. Along an increasing latitude, the forest types transit from tropical monsoon forests to subtropical evergreen forests, warm temperate deciduous broadleaf forests, temperate needleleaf and broadleaf mix forests and cold temperate needleleaf forests. As longitude declines from east to west, forests change to forest-steppe [41]. The carbon density of mature forests declines from mid-low latitudes $\left(20-30^{\circ} \mathrm{N}\right)$ to high latitudes $\left(50^{\circ} \mathrm{N}\right)$, which is in accordance with the latitudinal pattern at a global scale [26]. The difference is that the carbon density of mature forests in China does not appear relatively low value in the regions near $20^{\circ} \mathrm{N}$ and does not show high value in regions near $40^{\circ} \mathrm{N}$.

The horizontal patterns of carbon density are closely regulated by mean annual temperature and mean annual precipitation. Our work showed significantly positive relationships $(P<0.01)$ between carbon density and mean annual temperature and mean annual precipitation, which agrees with the previous findings at continental [42] and global scales [26]. Due to the similar patterns of temperature and precipitation in China, the amount of variance of carbon density of mature forests explained by temperature and precipitation together is close to the amount explained by temperature and precipitation separately.

\subsection{Climate controlled elevational patterns of carbon density of mature forests}

The elevational patterns of mature forests match their horizontal patterns [43] in forest type and carbon density. From low to high altitudes, the forest types change from monsoon forests to evergreen forests, deciduous broadleaf forests and needleleaf forests. The carbon density of mature forests on the four mountains showed three different elevational patterns: declining, declining-increasing and increasingdeclining. These elevational patterns all can be explained by climate limitation (Figure 7).

Temperature is the major control factor on carbon density of mature forests on Changbai Mountain and Wuyi Mountain. First, carbon density of mature forests decreases along rising elevation with a similar pattern for the two mountains. The pattern is in accord with the temperature gradient along rising elevation. Second, precipitation is abundant and increases along increasing altitude on both Changbai and Wuyi mountains. One noteworthy point is that although temperature and precipitation of Wuyi are significantly higher than that of Changbai, the carbon density is close in areas with similar altitude for the two mountains, which underlines the remarkable efficiency difference between the two regions in terms of using energy and precipitation to sequestrate carbon.

Temperature and precipitation are major factors controlling the carbon density of mature forests on Hengduan Mountain. On one hand, the carbon density increases first and then decreases along rising elevation, which is caused by decreased temperature and initially stable precipitation, then decreased precipitation along increasing elevation. The carbon density increases along rising altitude in areas lower than $3800 \mathrm{~m}$, but decreases along rising altitude in areas above that. In areas lower than $3800 \mathrm{~m}$, the carbon density is limited by precipitation availability. Along rising altitude, stable precipitation and decreased temperature together lead to increased available water for forests, and consequently increased carbon density. In areas over $3800 \mathrm{~m}$, temperature decreases to $5^{\circ} \mathrm{C}$ and even lower, and precipitation is less than $500 \mathrm{~mm}$. As a result, forest growth tends to be limited by temperature or precipitation. On the other hand, great carbon density variance was identified for areas with similar altitudes. Hengduan Mountain barriers the pass of prevailing winds from Indian Ocean, which leads to more precipitation along rising elevation on the western slopes, and creates wetter conditions suitable for forest growth, but drier conditions on the eastern slopes $[44,45]$. The different climates between windward and leeward slopes cause high variances of carbon density at similar elevations.

Precipitation is the major factor controlling carbon density of mature forests on Tianshan Mountain. The carbon density of all the mature forests increases along rising elevation in areas below $2000 \mathrm{~m}$, except on two sites located in Yili region. This pattern reflects an increased precipitation 


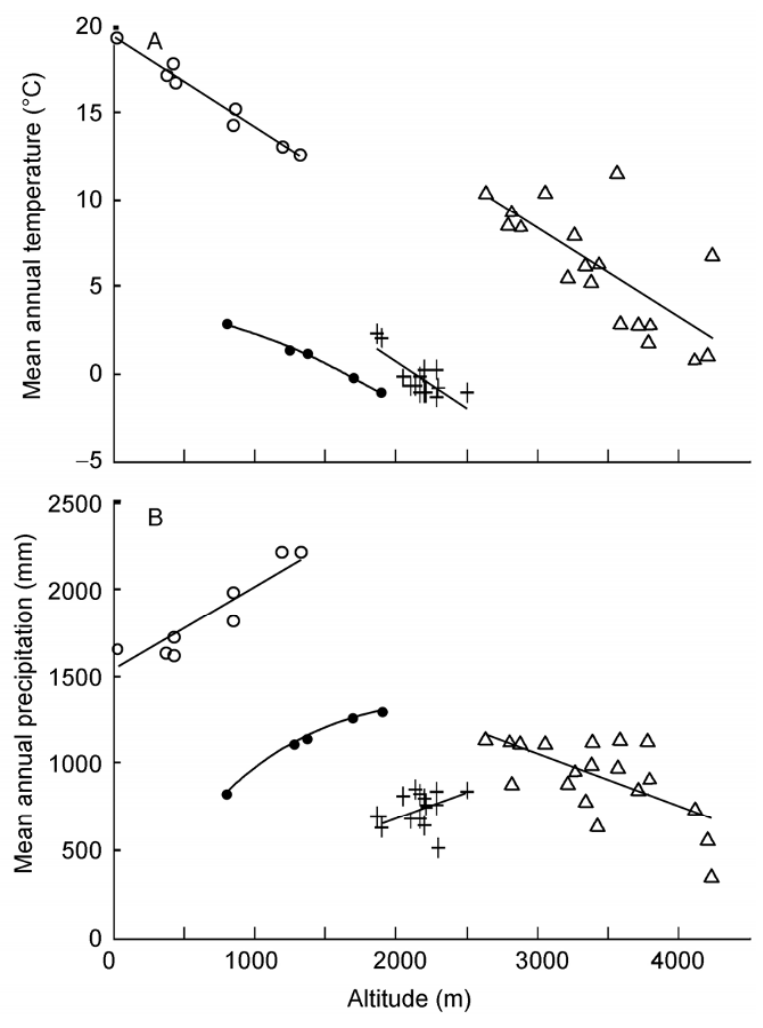

Figure 7 Elevational patterns of mean annual temperature (A) and mean annual precipitation (B). Wuyi Mountain in Fujian (open circle $\circ$ ), Changbai Mountain in Jilin (solid circle/black ball •), Tianshan Mountain in Xinjiang (plus + ) and Hengduan Mountain in Yunnan (triangle $\triangle$ ).

along rising elevation. Due to the non-availability of mature forests over $2500 \mathrm{~m}$ in our study, the declining trend of the carbon density of mature forests along increased elevation cannot be reflected, but we can image the declining trend because of temperature limitation.

\subsection{Carbon sequestration potential and its uncertainty}

The carbon density of Chinese forests increases as increasing forest ages, which means the forests have the potential to uptake carbon regardless of development stages and forest types (natural or planted forests). Maintaining the current forest area and taking the carbon density of mature forests as the reference level, we conservatively estimated the total CCC and CSP of Chinese forest biomass to be 19.87 and $13.86 \mathrm{Pg} \mathrm{C}$, respectively. These values are significantly higher than the results that use carbon density of pre-to-over mature forests from National Forest Resources Inventory as the reference level of $C C C$, which also used the space-for-time method and estimated the CSP at 4.27 Pg C [46]. One reason causing the discrepancy is that we take carbon density of mature forests of 80 years or older as the reference level of $C C C$. This stand age is older than the pre-mature stages of most forest species in China [7,47].

The estimated CSP in Chinese forests still involves much uncertainty. Besides the above-mentioned reference level uncertainty, forest area, climate and human activity also can significantly affect our estimation of forest CSP. First, choosing a suitable reference level of $C C C$ is critical. In this study, we chose the carbon density of mature forests as the reference level, and determined 80 years as the age threshold of mature forests at a country scale. In fact, the growth rates are different among biomes, and the age thresholds of mature forests should vary with biome types. Therefore, an improved approach is to determine a specific age threshold for each biome.

Secondly, different definitions on forest will affect the calculated forest area, which results in uncertainty in estimating $C C C$ of forest. For example, in scheme 1 and 2, the forest distribution data were based on Vegetation Atlas of China generated in the 1990s [37] and Global Land Cover 2000 generated in the 2000s, respectively. In addition to the data generation period, different definitions on forests can also lead to the discrepancy of forest area between the two datasets. Although both the Vegetation Atlas of China and Global Land Cover 2000 were interpreted from remote sensing data, the forest as defined in the former is the land growing trees and bamboos, excluding shrubland and non-timber forests, while the forests as defined in the latter include not only closed forests, but also open and burnt forests. Due to the difference of forest definition, the discrepancy of the estimated total $C C C$ between the scheme 1 and the scheme 2 is $8.4 \mathrm{Pg} \mathrm{C}$.

Thirdly, climate change can also cause uncertainty in assessing forest CSP. Climate change would infect spatial pattern of tree species [48] and $C C C$ of forests [21,49]. Estimating forest CSP under the past climate data would lead to some uncertainties. For example, the scheme 2 is based on Chinese Climate, and the scheme 3 is based on global climate. The estimated carbon carry capacity from the scheme 3 is higher than that from the scheme 2. The precipitation from Global Climate is higher than that from Chinese Climate, and the positive relationship between precipitation and carbon density implies more precipitation leads to higher carbon density in Chinese forests.

In addition, human activities also lead to uncertainty in assessing forest CSP. In China, human activities result in a wide carbon density difference among forest types. For example, in the eighth National Forest Resources Inventory [6], forests not only include woodland, but also bamboo (6.2 $\mathrm{Mhm}^{2}$ ), non-timber forests $\left(20.6 \mathrm{Mhm}^{2}\right)$ and shrubland (37.6 $\left.\mathrm{Mhm}^{2}\right)$. The latter three forest types cannot develop naturally to a climax status under the current forest management. Under different scenarios of human activities (i.e., afforestation, harvesting, management of non-timber forests), the carbon density also has notable difference for the same forest type. In addition, our results showed that subtropical forests have higher CSP than other biomes, but they are mainly fast-growing trees and have low residence time under the existing forest management [50]. Consequently, 
to achieve the $C S P$, we need to improve the modality of forest management and enhance the carbon stock capacity in Chinese forests.

\section{Conclusion}

The relationships between carbon density of mature forests and temperature, precipitation and stand age are positive in China. The latitudinal and elevational patterns of the carbon density can be explained by the patterns of temperature and precipitation. We used carbon density of mature forests as the reference level of $C C C$, the forest biomass in China conservatively have a total $C C C$ of $19.87 \mathrm{Pg} \mathrm{C}$, and have CSP of $13.86 \mathrm{Pg} \mathrm{C}$. Among the ecological zones in China, the subtropical forests have the highest total $C C C$ and $C S P$.

We gratefully acknowledge all the researchers who worked on the site inventory and analysis. This work was supported by the National Basic Research Program of China (2010CB833504), the CAS Strategic Priority Research Program (XDA05050702), and the National Natural Science Foundation of China (31290221).

1 Pan YD, Birdsey RA, Fang JY, Houghton R, Kauppi PE, Kurz WA, Phillips OL, Shvidenko A, Lewis SL, Canadell JG, Ciais P, Jackson RB, Pacala SW, McGuire AD, Piao SL, Rautiainen A, Sitch S, Hayes D. A large and persistent carbon sink in the world's forests. Science, 2011, 333: 988-993

2 Liu YC, Yu GR, Wang QF, Zhang YJ. Huge carbon sequestration potential in global forests. J Resour Ecol, 2012, 3: 193-201

3 Intergovernmental Panel on Climate Change. Intergovernmental Panel on Climate Change Guidelines for National Greenhouse Gas Inventories. Vol. 4 Agriculture, Forestry and Other Land Use, Prepared by the National Greenhouse Gas Inventories Programme. Eggleston S, Buendia L, Miwa K, Ngara T, Tanabe K, eds. Kanagawa: Institute for Global Environmental Strategies, 2006

4 Yu GR, Li XR, Wang QF, Li SG. Carbon storage and its spatial pattern of terrestrial ecosystem in china. J Resour Ecol, 2010, 1: 97-109

5 China Afforestation Committee and State Forestry Administration of China. Outline of China Afforestation Plan (2011-2020) (in Chinese). 2011, http://www.forestry.gov.cn/uploadfile/main/2011-7/file/20117-12-8920476e3e204817a8d33e821e5fdb44.pdf (accessed 21 May 2014)

6 State Forestry Administration of China. The Eighth National Forest Resources Inventory. http://www.forestry.gov.cn/gjslzyqc.html (accessed 21 May 2014)

7 Liu YC. Carbon carrying capacity and carbon sequestration potential of global forests based on the integrated analysis of inventory dataset (in Chinese). Dissertation for Doctoral Degree. Beijing: Institute of Geographical Sciences and Natural Resources Research, Chinese Academy of Sciences, 2013

8 Wang XK, Feng ZW. The potential to sequester atmospheric carbon through forest ecosystems in China (in Chinese). Chin J Ecol, 2000, 19: $72-74$

9 Wang CM, Shao B, Wang RN. Carbon sequestration potential of ecosystem of two main tree species in Northeast China (in Chinese). Acta Ecol Sin, 2010, 30: 1764-1772

10 Liu YC, Wang QF, Yu GR, Zhu XJ, Zhan XY, Guo Q, Yang H, Li $\mathrm{SG}, \mathrm{Hu} \mathrm{ZM}$. Ecosystems carbon storage and carbon sequestration potential of two main tree species for the Grain for Green Project on China's hilly Loess Plateau (in Chinese). Acta Ecol Sin, 2011, 31: 4277-4286

11 Lieth H. Primary production: terrestrial ecosystems. Hum Ecol, 1973,
1: 303-332

12 Ju WM, Chen JM, Harvey D, Wang SQ. Future carbon balance of China's forests under climate change and increasing $\mathrm{CO}_{2}$. J Environ Manage, 2007, 85: 538-562

13 Schmid S, Thürig E, Kaufmann E, Lischke H, Bugmann H. Effect of forest management on future carbon pools and fluxes: a model comparison. Forest Ecol Manage, 2006, 237: 65-82

14 Wu QB, Wang XK, Duan XN, Deng LB, Lu F, Ouyang ZY, Feng ZW. Carbon sequestration and its potential by forest ecosystems in China (in Chinese). Acta Ecol Sin, 2008, 28: 517-524

15 Eggers J, Lindner M, Zudin S, Zaehle S, Lisk J. Impact of changing wood demand, climate and land use on European forest resources and carbon stocks during the 21st century. Glob Change Biol, 2008, 14: 2288-2303

16 Turner DP, Koerper GJ, Harmon ME, Lee JJ. Carbon sequestration by forests of the United States. Current status and projections to the year 2040. Tellus B, 1995, 47: 232-239

17 Thomas S, Malczewski G, Saprunoff M. Assessing the potential of native tree species for carbon sequestration forestry in northeast China. J Environ Manage, 2007, 85: 663-671

18 Woodbury PB, Smith JE, Heath LS. Carbon sequestration in the US forest sector from 1990 to 2010. Forest Ecol Manage, 2007, 241: 14-27

19 Tan ZH, Zhang YP, Schaefer D, Yu GR, Liang NS, Song QH. An old-growth subtropical Asian evergreen forest as a large carbon sink. Atmos Environ, 2011, 45: 1548-1554

20 Yan JH, Zhang YP, Yu GR, Zhou GY, Zhang LM, Li K, Tan ZH, Sha LQ. Seasonal and inter-annual variations in net ecosystem exchange of two old-growth forests in southern China. Agr Forest Meteorol, 2013, 182-183: 257-265

21 Lewis SL, Lopez-Gonzalez G, Sonké B, Affum-Baffoe K, Baker TR, Ojo LO, Phillips OL, Reitsma JM, Lee W, Comiskey JA, Marie-Noël DK, Ewango CEN, Feldpausch TR, Hamilton AC, Gloor M, Hart T, Hladik A, Lloyd J, Lovett JC, Makana JR, Malhi Y, Mbago FM, Ndangalasi HJ, Peacock J, Peh KSH, Sheil D, Sunderland Terry, Swaine MD, Taplin J, Taylor D, Thomas SC, Votere R, Wöll H. Increasing carbon storage in intact African tropical forests. Nature, 2009, 457: 1003-1006

22 Muller-Landau HC. Carbon cycle: sink in the African jungle. Nature, 2009, 457: 969-970

23 Intergovernmental Panel on Climate Change. IPCC Guidelines for National Greenhouse Gas Inventories: Volume 3 Reference Manual, Chapter 5 Land-Use Change \& Forestry. Brown S, Sokona Y, Winjum J, Kokorin A, Lorenzini M, eds. 1996

24 Clements FE. Plant Succession: an Analysis of the Development of Vegetation. Washington, DC: Carnegie Institution of Washington, 1916

25 Odum EP. The strategy of ecosystem development. Science, 1969, 164: $262-270$

26 Liu YC, Yu GR, Wang QF, Zhang YJ. How temperature, precipitation and stand age control the biomass carbon density of global mature forests. Global Ecol Biogeogr, 2014, 23: 323-333

27 Jarvis PG, Morison JIL, Chaloner WG, Cannell, MGR. Roberts J, Jones HG, Amtmann R. Atmospheric carbon dioxide and forests [and discussion]. Phil Trans R Soc Lond B, 1989, 324: 369-392

28 Keith H, Mackey BG, Lindenmayer DB. Re-evaluation of forest biomass carbon stocks and lessons from the world's most carbon-dense forests. Proc Natl Acad Sci USA, 2009, 106: 11635-11640

29 Luo YJ, Wang XK, Zhang XQ, Zhu JH, Zhang ZJ, Hou ZH. Biomass estimation factors of Larix principis-rupprechtii plantations in Northern China (in Chinese). Sci Silv Sin, 2010, 46: 6-11

30 Luo TX. The distribution patterns and modeling of biomass and net primary production in China main forests (in Chinese). Dissertation for Doctoral Degree. Beijing: Committee of Integrate Investigation of Natural Resources, Chinese Academy of Sciences, 1996

31 State Forestry Administration of China. National Forestry Resources Statistic (1999-2003) (in Chinese). Beijing: China Forestry Publishing House, 2005

32 Fang JY, Liu GH, Xu SL. Biomass and net production of forest veg- 
etation in China (in Chinese). Acta Ecol Sin, 1996, 16: 497-508

33 Pan YD, Luo TX, Birdsey R, Hom J, Melillo J. New estimates of carbon storage and sequestration in China's forests: effects of age-class and method on inventory-based carbon estimation. Climatic Change, 2004, 67: 211-236

34 Yu GR, He HL, Liu XA, Niu D. Study on spatialization technology of terrestrial eco-information in China (I): the approach of spatialization in meteorology/climate information (in Chinese). J Nat Resour, 2004, 19: 537-544

35 Liu XA, Yu GR, Fan LS, Li ZQ, He HL, Guo XB, Ren CY. Study on spatialization technology of terrestrial eco-information in China (III): temperature and precipitation (in Chinese). J Nat Resour, 2004, 19: $818-825$

36 Editorial Committee of Vegetation Atlas of China, Chinese Academy of Sciences. 1:1000 000 Vegetation Atlas of China (in Chinese). Beijing: Science China Press, 2001

37 Editorial Committee of Vegetation Atlas of China, Chinese Academy of Sciences (Zhang XS, ed). Vegetation Map of China and Its Geographic Pattern: Illustration of the Vegetation Map of the People's Republic of China (1:1 000 000) (in Chinese). Beijing: Geology Publishing House, 2007

38 New M, Lister D, Hulme M, Makin I. A high-resolution data set of surface climate over global land areas. Climate Res, 2002, 21: 1-25

39 Hijmans RJ, Cameron SE, Parra JL, Jones PG, Jarvis A. Very high resolution interpolated climate surfaces for global land areas. Int $\mathbf{J}$ Climatol, 2005, 25: 1965-1978

40 Food and Agriculture Organization of the United Nations. Global Ecological Zoning for the Global Forest Resources Assessment 2000, Rome, Italy. 2001, http://www.fao.org/docrep/006/ad652e/ad652e00. HTM (accessed 21 May 2014)

41 Huang BW. Draft for comprehensive physical regionalization in
China (in Chinese). Chin Sci Bull, 1959, 4: 594-602

42 Stegen JC, Swenson NG, Enquist BJ, White EP, Phillips OL, Jørgensen PM, Weiser MD, Monteagudo Mendoza A, Núñez Vargas P. Variation in above-ground forest biomass across broad climatic gradients. Global Ecol Biogeogr, 2011, 20: 744-754

43 Randin CF, Paulsen J, Vitasse Y, Kollas C, Wohlgemuth T, Zimmermann NE, Körner, C. Do the elevational limits of deciduous tree species match their thermal latitudinal limits? Global Ecol Biogeogr, 2013, 22: 913-923

44 Yang QY, Zheng D, Liu YH. Physical characteristic of dry valleys in Hengduan Mountain and its exploitation and utilization (in Chinese). J Arid Land Resour Environ, 1988, 2: 17-23

45 He YB, Lu PZ, Zhu T. Causes for the formation of dry-hot valleys in Hengduan Mountain-Yunnan Plateau (in Chinese). Resour Sci, 2000, 22: 69-72

46 Guo ZD, Hu HF, Li P, Li NY, Fang JY. Spatio-temporal changes in biomass carbon sinks in China's forests during 1977-2008. Sci China Life Sci, 2013, 56: 661-671

47 Xiao XW, ed. National forest inventory of China (in Chinese). Beijing: Chinese Forestry Publishing House, 2005

48 Peng $\mathrm{CH}$, Ma ZH, Lei XD, Zhu QA, Chen H, Wang WF, Liu SR, Li WZ, Fang XQ, Zhou XL. A drought-induced pervasive increase in tree mortality across Canada's boreal forests. Nat Clim Change, 2011, 1: 467-471

49 Ma ZH, Peng CH, Zhu QA, Chen H, Yu GR, Li WZ, Zhou XL, Wang WF, Zhang WH. Regional drought-induced reduction in the biomass carbon sink of Canada's boreal forests. Proc Natl Acad Sci USA, 2012, 109: 2423-2427

50 Zhou T, Shi PJ, Jia GS, Li XJ, Luo YQ. Spatial patterns of ecosystem carbon residence time in Chinese forests. Sci China Earth Sci, 2010, 53: $1229-1240$

Open Access This article is distributed under the terms of the Creative Commons Attribution License which permits any use, distribution, and reproduction in any medium, provided the original author(s) and source are credited. 